\title{
Biomarker validation of cardiac magnetic resonance analysis of regional myocardial fibrosis in ischaemic heart disease
}

Benedict T Costello ${ }^{1}$, Leah M lles ${ }^{2 *}$, Dion Stub², Andris Ellims², Karen Smith ${ }^{3}$, Stephen Bernard ${ }^{2}$, Ziad Nehme $^{4}$, Janet Bray ${ }^{2}$, Peter Cameron², lan Meredith ${ }^{5}$, David Kaye ${ }^{2}$, Andrew Taylor ${ }^{2,1}$

From 19th Annual SCMR Scientific Sessions

Los Angeles, CA, USA. 27-30 January 2016

\section{Background}

Late gadolinium enhancement (LGE) with CMR is commonly assumed to represent myocardial fibrosis; however, comparative human histological data are limited, and there is no consensus on the most accurate method for LGE quantitation. We evaluated the relationship between CMR assessment of regional fibrosis and infarct size assessment using serial biomarkers after ST segment elevation myocardial infarction (STEMI).

\begin{tabular}{|l|c|c|c|c|c|c|c|c|c|c|}
\hline \multicolumn{10}{|c|}{ Spearman's rho: Biomarkers and LGE mass } \\
\hline & $\mathrm{n}$ & Visual & FWHM & 2SD & 3SD & 4SD & 5SD & 6SD & 8SD & 10SD \\
CK & & & & & & & & & & \\
\hline Peak & 96 & .771 & 0.707 & .741 & .781 & .807 & .819 & .816 & .798 & .788 \\
Tal & 88 & .804 & 0.715 & .730 & .777 & .819 & .830 & .834 & .828 & .821 \\
AUC & 95 & .705 & 0.670 & .688 & .727 & .746 & .758 & .755 & .737 & .729 \\
CK & & & & & & & & & & \\
\hline AUC & 87 & .818 & 0.773 & .756 & .804 & .845 & .853 & .852 & .842 & .838 \\
Tal & & & & & & & & & & \\
\hline
\end{tabular}

All correlation coefficients are significant at the level $<0.001$.

Figure 1 Correlation between infarct size assessment using biomarkers and CMR-LGE

${ }^{2}$ Alfred Hospital, Melbourne, VIC, Australia

Full list of author information is available at the end of the article

(c) 2016 Costello et al. This is an Open Access article distributed under the terms of the Creative Commons Attribution License (http:// creativecommons.org/licenses/by/4.0), which permits unrestricted use, distribution, and reproduction in any medium, provided the original work is properly cited. The Creative Commons Public Domain Dedication waiver (http://creativecommons.org/publicdomain/ zero/1.0/) applies to the data made available in this article, unless otherwise stated. 


\section{Methods}

Ninety-five patients treated for STEMI $(59 \pm 10$ years, 85\% male) underwent CMR six months after infarction. Fibrosis was quantified by CMR-LGE using visual and automated thresholds, and compared with the rise in serum biomarkers.

\section{Results}

Quantification methods had a strong influence on the infarct size assessment with CMR-LGE. Significant correlations were observed between LGE and biomarkers across a range of signal intensity thresholds (range: 2-10 standard deviations [SD] above reference myocardium), however there was a wide range with respect to estimation of total LGE size (from $6.8 \pm 7.7$ to $32.1 \pm 11.3$ grams) and a smaller variation in the correlation with peak troponin level ( $R$-values ranging from 0.715 to $0.834)$. The strongest correlation was observed at thresholds of 5 and $6 \mathrm{SD}(\mathrm{R}=0.830, \mathrm{P}<0.001$ and $\mathrm{R}=$ $0.834, \mathrm{P}<0.001)$.

\section{Conclusions}

There is a wide variation for the correlation between CMR-LGE quantification of infarct size and biomarker release following STEMI at a range of automated thresholds, with the strongest correlations at 5SD and 6SD thresholds.

\section{Authors' details}

${ }^{1}$ Baker IDI Heart and Diabetes Institute, Melbourne, VIC, Australia. ${ }^{2}$ Alfred Hospital, Melbourne, VIC, Australia. ${ }^{3}$ Monash University, Melbourne, VIC, Australia. ${ }^{4}$ Ambulance Victoria, Melbourne, VIC, Australia. ${ }^{5}$ Monash Heart, Melbourne, VIC, Australia.

Published: 27 January 2016
Submit your next manuscript to BioMed Central and take full advantage of:

- Convenient online submission

- Thorough peer review

- No space constraints or color figure charges

- Immediate publication on acceptance

- Inclusion in PubMed, CAS, Scopus and Google Scholar

- Research which is freely available for redistribution

Submit your manuscript at www.biomedcentral.com/submit
C Biomed Central 